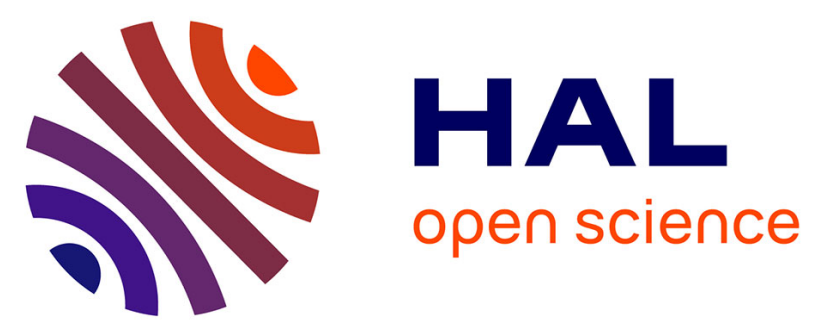

\title{
The in vivo performance of ferrocenyl tamoxifen lipid nanocapsules in xenografted triple negative breast cancer
}

Anne-Laure Lainé, Eric Adriaenssens, Anne Vessières, Gérard Jaouen, Cyril Corbet, Emilie Desruelles, Pascal Pigeon, Robert-Alain Toillon, Catherine Passirani

\section{To cite this version:}

Anne-Laure Lainé, Eric Adriaenssens, Anne Vessières, Gérard Jaouen, Cyril Corbet, et al.. The in vivo performance of ferrocenyl tamoxifen lipid nanocapsules in xenografted triple negative breast cancer. Biomaterials, 2013, 34 (28), pp.6949-6956. 10.1016/j.biomaterials.2013.05.065 . hal-01230382

\section{HAL Id: hal-01230382 \\ https://hal.science/hal-01230382}

Submitted on 25 Oct 2018

HAL is a multi-disciplinary open access archive for the deposit and dissemination of scientific research documents, whether they are published or not. The documents may come from teaching and research institutions in France or abroad, or from public or private research centers.
L'archive ouverte pluridisciplinaire HAL, est destinée au dépôt et à la diffusion de documents scientifiques de niveau recherche, publiés ou non, émanant des établissements d'enseignement et de recherche français ou étrangers, des laboratoires publics ou privés. 


\title{
The in vivo performance of ferrocenyl tamoxifen lipid nanocapsules in xenografted triple negative breast cancer
}

Anne-Laure Lainé ${ }^{\mathrm{a}, \mathrm{b}}$, Eric Adriaenssens ${ }^{\mathrm{c}, \mathrm{d}}$, Anne Vessières ${ }^{\mathrm{e}}$, Gérard Jaouen ${ }^{\mathrm{e}}$, Cyril Corbet ${ }^{\mathrm{d}}$

${ }^{\mathrm{f}}$, Emilie Desruelles ${ }^{\mathrm{d}, \mathrm{f}}$, Pascal Pigeon ${ }^{\mathrm{e}}$, Robert-Alain Toillon ${ }^{\mathrm{d}, \mathrm{f}}$, Catherine Passirani ${ }^{\mathrm{a}, \mathrm{b}, *}$

${ }^{a}$ LUNAM Université - Micro et Nanomédecines biomimétiques, F-49933 Angers, France

${ }^{\mathrm{b}}$ Inserm - U1066 IBS-CHU, F-49933 Angers, France

${ }^{\mathrm{c}}$ CNRS UMR 8527, Lille F-59021, France

${ }^{\mathrm{d}}$ Université Lille 1, Villeneuve d'Ascq F-59655, France

${ }^{\text {e }}$ CNRS, UMR 7576, Ecole Nationale Supérieure de Chimie de Paris, F-75231, France

${ }^{\mathrm{f}}$ Inserm U908, Villeneuve d'Ascq F-59655, France

* Corresponding author. INSERM U1066, IBS-CHU Angers, 4 rue Larrey, 49933

Angers Cedex 9, France. Tel.: +33 (0)2 446885 34; fax: +33 (0)2 44688546.

E-mail address: Catherine.passirani@univ-angers.fr (C. Passirani).

Keywords: Ferrocene, Nanoparticle, Triple negative breast cancers, Bioluminescence

\begin{abstract}
:
Triple-negative breast cancers (TNBC) represent the most aggressive form of breast cancers and their treatment are challenging due to the tumor heterogeneity. The high death rate and the limited systemic treatment options for TNBC necessitate the search for alternative
\end{abstract}


chemotherapeutics. We previously found that FcOHTAM, an organometallic derivative of hydroxytamoxifen, showed in vitro a strong antiproliferative effect on various breast cancer cell lines, including MDA-MB-231 cells, the archetype of TNBC. In this study, we developed stealth FcOHTAM loaded lipid nanocapsules (LNCs) to further evaluate this novel drug on a TNBC xenografted model. Cell cycle analysis of MDA-MB-231 cells confirmed the preservation of the drug activity through LNCs causing a cycle arrest in phase $\mathrm{S}$ after $48 \mathrm{~h}$ exposure at the $\mathrm{IC}_{50}$ concentration $(2 \mu \mathrm{M})$. Two intraperitoneal injections of FcOHTAM loaded LNCs (20 mg/kg) administered to luciferase-transfected MDA-MB-231 tumors bearing mice led to a marked delay in tumor growth. As a consequence, a significantly lower tumor volume was obtained at the end of the experiment with a difference of $36 \%$ at day 38 compared to the untreated group. These results represent the first evidence of an in vivo effect of FcOHTAM and ferrocenyl derivatives in general on xenografted breast tumors.

\section{Introduction}

Breast cancer $(\mathrm{BC})$ is the most frequently diagnosed cancer in women worldwide accounting for $23 \%$ of the total cancer cases [1]. Thanks to medical progress in cancer diagnosis and therapy including earlier detection, increased awareness and improved treatment, breast cancer survival has been increasing since about 1990. However, despite these advances, breast cancer remains the principle cause of death from cancer among women, representing $14 \%$ of global cancer deaths (worldwildbreastcancer.com).

Among the different BC subtypes, triple negative breast cancer (TNBC) defined by the absence of estrogen receptor alpha (ER $\alpha)$, progesterone receptor (PR) and human epidermal growth factor receptor 2 (HER2), accounts for $15-20 \%$ of all breast cancer cases and is responsible for a high rate of mortality [2,3]. TNBC generally occurs in younger women and represents the most aggressive form associated with a high risk of recurrence, visceral and 
central nervous system metastases and early death. The lack of standard therapeutic receptors makes TNBC insensitive to endocrine therapy such as tamoxifen $\left(\right.$ Nolvadex $\left.^{\circledR}\right)$ used in ER $\alpha$ (+) cancer treatment [4] or to trastuzumab $\left(\right.$ Herceptin $\left.^{\circledR}\right)$ commonly used for HER2 (+) tumors. Additionally, TNBC is further characterized by a biological heterogeneity within its own subgroup. Consequently, there is currently no targeted therapy for TNBC and no treatment protocole (schedule and choice of chemotherapeutics) has been standardized so far, making TNBC a major challenge for breast oncologists. Current researches focus on the development of innovative therapeutics with alternative biological activity such as PARP (polyadenosine diphosphate ribose polymerase) inhibitor, antiangiogenic agent or tumor necrosis factorrelated apoptosis-inducing ligand [5]. In this context and with the growing interest in metalbased drug [6], Jaouen's group has synthesized a range of ferrocenyl tamoxifen derivatives called ferrocifenes resulting of the combination of a ferrocene moiety with the tamoxifen (TAM) scaffold (Fig. 1) [7].

Since its FDA approval in 1998, TAM has been the oldest and most prescribed SERM (selective estrogen receptor modulator) and it plays the role of antagonist of the estrogen receptor via its active metabolite 4-hydroxytamoxifen (OH-TAM). TAM has been used for the management of advanced or metastatic estrogen dependent breast cancer, but also as adjuvant therapy, preoperative treatment and chemoprevention [8,9]. Despite its great achievements, $30 \%$ of $\operatorname{ER} \alpha(+)$ breast cancer displays a de novo resistance to TAM [10] while $40 \%$ of $\mathrm{ER} \alpha(+)$ tumors acquire resistance over the treatment period [11]. Besides this resistance, TAM efficacy is impeded with severe side effects caused by the lack of selectivity of the drug against tumors cells such as endometrial cancers [12] and ovarian cyst [13]. Finally, as aforementioned, TAM is inefficient on $\mathrm{ER} \alpha(-)$ breast cancer cases which includes TNBC [14]. The strategy of coupling a ferrocene to the hydroxytamoxifen was therefore meant to supplement TAM with a 
redox entity in order to overcome the therapeutic limitation encountered with the organic analogue.

Interestingly, previous in vitro studies demonstrated that FcOHTAM induced cell growth arrest and senescence of both hormone-dependent and independent breast cancer cells at low doses. This original effect is not related to tamoxifen-induced apoptosis which can be observed with high doses of TAM $[15,16]$. This first result proved the efficient contribution of the ferrocenyl moiety in potentiating the anticancer mechanism of the complex. To conduct in vivo evaluations, it was necessary to address the water solubility issue of this lipophilic molecule. Today, nanomedicines have appeared as a compelling system to develop an injectable formulation of FcOHTAM offering great benefits such as increased bioavailability, protection against in vivo degradation and enhancement of pharmacokinetic properties. Among the manifold types of nanovehicles, lipid nanocapsules (LNCs) [17], composed of an oily core and a surfactant-made shell, already proved their efficiency to entrap and transport the ferrociphenol $(\mathrm{FcdiOH}) \mathrm{drug}$, another member of the ferrocifen family. The anticancer activity of FcdiOH was widely investigated on brain tumor models through lipid nanocapsules and favorable outcomes showed the promising efficiency of this ferrocenyl based drug [1820], encouraging the preclinical FcOHTAM evaluation via LNCs.

The aim of the present work was therefore to develop a suspension of stealth FcOHTAMLNCs and, thereafter, to assess the response of mice bearing MDA-MB-231 xenografted tumors, a TNBC model resistant to tamoxifen treatment.

\section{Materials and methods}

\subsection{Chemical materials}

Fc-OH-TAM was prepared by a McMurry cross-coupling reaction as previously described [21]. The lipophilic Labrafac ${ }^{\circledR}$ WL1349 (caprylic-capric acid triglycerides) was purchased 
from Gattefosse S.A. (Saint-Priest, France). Lipoïd ${ }^{\circledR}$ S75-3 (soybean lecithin at $69 \%$ of phosphatidylcholine) provided by Lipoïd Gmbh (Ludwigshafen, Germany); Solutol ${ }^{\circledR}$ HS15 (a mixture of free polyethylene glycol 660 and polyethylene glycol 660 hydroxystearate) by BASF (Ludwigshafen, Germany) and $\mathrm{NaCl}$ by Prolabo (Fontenay-sous-bois, France). Deionized water was acquired from a Milli-Q plus system (Millipore, Paris, France) and sterile water from Cooper (Melun, France). 1,2-DiStearoyl-sn-glycero-3PhosphoEthanolamine-N-[methoxy-(polyethyleneglycol)-2000] (DSPEmPEG2000) (Mean Molecular Weight $(\mathrm{MMW})=2805 \mathrm{~g} / \mathrm{mol}$ ) was purchased from Avanti Polar Lipids (Alabaster, USA).

\subsection{Preparation of Fc-OH-TAM-loaded lipid nanocapsules}

The LNC vehicle was prepared according to a phase inversion method as previously described [2]. Briefly, the preparation process involved 2 steps. Step I consisted of mixing all the excipients $\left(\right.$ Solutol $^{\circledR}$ HS15 $(17.2 \% \mathrm{w} / \mathrm{w})$, Lipoid $^{\circledR}(1.5 \% \mathrm{w} / \mathrm{w})$, Labrafac $^{\circledR}(20.8 \% \mathrm{w} / \mathrm{w})$, $\mathrm{NaCl}(0.5 \% \mathrm{w} / \mathrm{w})$ and water $(60 \% \mathrm{w} / \mathrm{w}))$ under magnetic stirring and heating from room temperature to $90{ }^{\circ} \mathrm{C}$. Three cycles of progressive cooling and heating between 90 and $60{ }^{\circ} \mathrm{C}$ were then carried out. Step II was an irreversible shock induced by sudden dilution with water $(28.5 \%(\mathrm{v} / \mathrm{v}))$ applied to the mixture at $70-72{ }^{\circ} \mathrm{C}$. Slow magnetic stirring was then applied to the suspension for $5 \mathrm{~min}$.

Fc-OH-TAM loaded LNCs were prepared according to this above-mentioned process with drug addition as a solid powder at step 1 to the other excipients in order to obtain a final concentration of $8 \mathrm{mg} / \mathrm{mL}(2.8 \% \mathrm{w} / \mathrm{w})$. The drug was solubilized during the heating step and ultimately encapsulated over the last cooling step.

\subsection{Post-insertion of DSPE-mPEG(2000) at the LNC surface}


To design stealth LNCs, DSPE-mPEG2000 was grafted onto the surface of LNCs at the concentration of $10 \mathrm{mM}$ by the post-insertion technique as previously described [22]. Briefly, DSPE-mPEG2000 was added to the LNC suspension preheated at $60{ }^{\circ} \mathrm{C}$. The mixture was placed under magnetic stirring for $2 \mathrm{~h}$ at $60{ }^{\circ} \mathrm{C}$, and, finally the insertion was quenched in an ice bath for $1 \mathrm{~min}$. This technique is commonly called PEGylation, referred to as the insertion of PEG chains on the carrier surface.

\subsection{LNC characterization}

The determination of the drug loading was achieved by spectrophotometry at $254 \mathrm{~nm}$ after dissolving $10 \mu \mathrm{L}$ of LNCs into $5 \mathrm{~mL}$ of methanol (Fisher chemical). The calibration curve, ranged from $10 \mu \mathrm{M}$ to $100 \mu \mathrm{M}$, was also prepared in methanol.

The average hydrodynamic diameter of nanocapsules were determined at $25{ }^{\circ} \mathrm{C}$, in triplicate, by using a Malvern Zetasizer ${ }^{\circledR}$ (Nano Series DTS 1060, Malvern Instruments S.A.,Worcestershire, UK). For the measurement, the LNCs were diluted at 1:100 (v/v) in deionised water.

\subsection{Tumour cell line and culture}

MDA-MB-231 breast cancer cell line was obtained from the American Type Culture Collection (ATCC) and routinely grown in Dulbecco modified Minimal Essential Medium (DMEM) supplemented with $10 \%$ inactivated FBS (Fetal Bovine Serum) (Invitrogen Corporation, Cergy-Pontoise, France), 2 mM L-glutamine, $1 \%$ nonessential amino acids, 40 $\mathrm{UI} / \mathrm{ml}$ penicillin, $40 \mu \mathrm{g} / \mathrm{ml}$ streptomycin at $37{ }^{\circ} \mathrm{C}$ in $5 \% \mathrm{CO}_{2}$-humidified atmosphere.

MDA-MB-231 cells used in SCID mice experiment harbored stable transfection of Renilla hRLuc (Renilla reniformis) reporter gene. Cell transfections were done using pGL4 Luciferase receptor vector (promega) and the Cell Line Nucleofector Kit V (Lonza) according 
to the manufacturer's instructions. Cells were selected with hygromycin B $(800 \mu \mathrm{g} / \mathrm{ml}$, Invitrogen), the resulting hygromycin resistant cell populations were stored as frozen stocks and used for all the experiments within 20 passages.

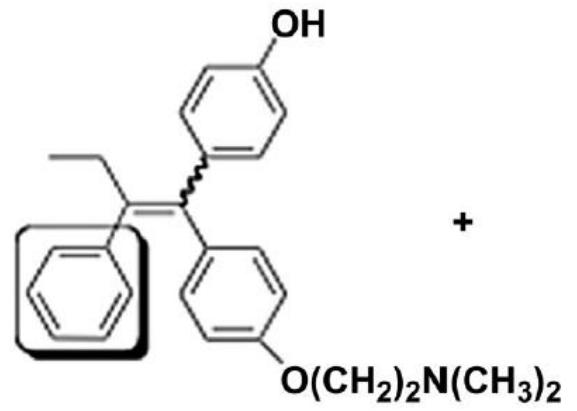

Hydroxytamoxifen (OHTam)

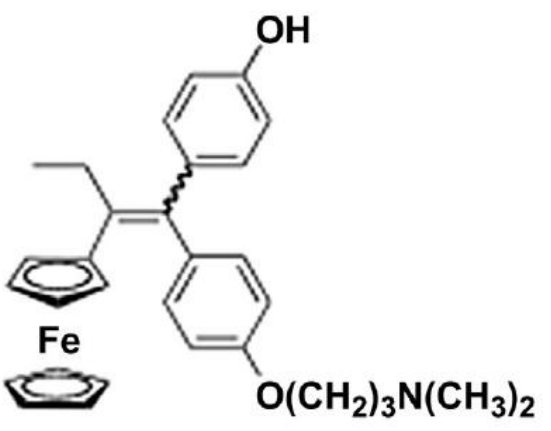

FcOHTam

Fig. 1. Schematic coupling between a hydroxytamoxifen and a ferrocene resulting in the ferrocenyl tamoxifen derivative.

\subsection{In vitro cell viability}

A suspension of MDA-MB-231 cells $\left(0.95 \times 10^{4}\right.$ cells $\left./ \mathrm{mL}\right)$ was put on every well of the 24-well plates for $48 \mathrm{~h}$. On day 2, the culture media was removed and cells were treated with increasing concentrations of FcOHTAM (0.01-100 $\mu \mathrm{mol} / \mathrm{L})$ from the various dosage form including free FcOHTAM, conventional LNCs and stealth LNCs. The free FcOHTAM (nonencapsulated drug) was solubilized in absolute ethanol at a concentration of $20 \mathrm{mg} / \mathrm{mL}$ and then diluted in the culture media to obtain the highest concentration $(100 \mu \mathrm{mol} / \mathrm{L})$. The different types of LNC suspensions were diluted likewise in the culture media in order to obtain a concentration of $100 \mu \mathrm{mol} / \mathrm{L}$. The other low concentrations were obtained by $1: 10$ cascade dilution from the $100 \mu \mathrm{mol} / \mathrm{L}$ concentration. The toxicity of the two kinds of unloaded LNCs was also evaluated with this antiproliferative assay by carrying out the same dilutions as for the loaded LNCs. 
After $72 \mathrm{~h}$ incubation at $37^{\circ} \mathrm{C}$, the media containing treatments were replaced by fresh media. Cell survival percentage was estimated by the MTS (3-(4,5-dimethylthiazol-2-yl)-5-(3carboxymethoxyphenyl)-2-(4-sulfophenyl)-2H-tetrazolium) survival assay (Promega, Lyon, France). MTS solution (100 $\mu \mathrm{l})$ was added into each well, and the plates were incubated at 37 ${ }^{\circ} \mathrm{C}$ for $2 \mathrm{~h} \mathrm{30}$. The optical density values (OD) were measured at $490 \mathrm{~nm}$ for dark purple intensity and at $750 \mathrm{~nm}$ for subtraction of background using a multiwell-scanning spectrophotometer (Multiskan Ascent, Labsystems SA, Cergy-pontoise, France). The maximal absorbance was determined by incubating cells with culture media and was considered as $100 \%$ survival. All experiments were performed in triplicate and presented as Mean \pm SD.

\subsection{Cell cycle analysis}

$1 \times 10^{5}$ MDA-MB-231 cells were plated in $60 \mathrm{~mm}$ dishes in DMEM with phenol red supplemented with $10 \%$ stripped foetal bovine serum for $24 \mathrm{~h}$. Cells were then treated with increasing concentration of free FcOHTAM and with LNC and stealth-LNC containing FcOHTAM. Cell cycle analyses were then process after 24,48 and $72 \mathrm{~h}$ of treatment. At the end of the experiment, the cells were trypsinized and washed twice with PBS. They were subsequently incubated in PBS containing RNAse A $\left(50 \mu \mathrm{g} / \mathrm{ml}, 15 \mathrm{~min}, 20{ }^{\circ} \mathrm{C}\right)$ and then in PBS containing propidium iodide $\left(20 \mu \mathrm{g} / \mathrm{ml}, 4 \mathrm{~h}, 20^{\circ} \mathrm{C}\right.$, in the dark). Cell cycle was analyzed with Cyan LX9 cytometer (Beckman Coulter, France) and data were analyzed by a multicycle software (phoenix Flow systems, San Diego, USA).

\subsection{In vitro complement activation}

The complement consumption was evaluated in normal human serum (NHS) (provided by the Etablissement Français du Sang, CHU, Angers, France) by measuring the residual 
haemolytic capacity of the serum complement after contact with the different particles. The technique, according to the procedure described elsewhere [23], consisted in dosing the amount of serum able to haemolyse $50 \%$ of a fixed number of sensitized sheep erythrocytes with rabbit anti-sheep erythrocyte antibodies (CH50 unit). Complement activation was presented as a function of the nanoparticle surface area which was calculated as previously described [24]. All

experiments were performed in triplicate.

\subsection{Animals and implantation of tumor cells}

Six-week-old female severe combined immunodeficient (SCID) mice were purchased from Pasteur Institute of Lille and acclimatized for at least two weeks. Mice were maintained under a $12 \mathrm{~h} \mathrm{light/dark} \mathrm{cycle} \mathrm{at} \mathrm{a} \mathrm{temperature} \mathrm{of} 20{ }^{\circ} \mathrm{C}-22{ }^{\circ} \mathrm{C}$. Food and water were available $\mathrm{ad}$ libitum. Mice were maintained in accordance with the Institutional Animal Care and Use Committee procedures and guidelines. The protocol used was approved by the regional ethic committee according to legislation. MDA-MB-231 cells were harvested and resuspended in PBS before subcutaneous injection into flanks $\left(3 \times 10^{6}\right.$ cells per mice). At day 14 and 19 , treatments (PBS, unloaded stealth LNCs, stealth FcOHTAM-LNCs) were applied intraperitoneally $(20 \mathrm{mg} / \mathrm{kg})$. To determine the tumor volume, each mouse was monitored at the indicated time using a bioluminescence imager (IVIS Lumina XR - CaliperLS).

\subsection{Statistical analysis}

Results were expressed as a mean \pm SEM. Statistical significance between control and treated groups was evaluated using Mann and Withney test.

\section{Results}




\subsection{Physicochemical properties of LNC suspensions}

The FcOHTAM concentration into LNCs was settled at $8 \mathrm{mg} / \mathrm{mL}$ in order to deliver the desired dose. At this concentration, the entrapment efficiency reached 100\% (data not shown). The physicochemical characteristics of the LNC suspensions including hydrodynamic diameter and zeta potential are summarized in Table 1.

Regarding the cargo size, the FcOHTAM entrapment into LNCs did not alter the size compared to unloaded LNCs as similar sizes were obtained. Stealth LNCs (unloaded and loaded with FcOHTAM) obtained after PEGylation showed a slight increase in size compared to conventional LNCs.

The apparent surface charge was evaluated through zeta potential measurement. As pointed out in Table 1, FcOHTAM entrapment markedly increased the zeta potential from $-6.6 \mathrm{mV}$ to +22.7 mV . After DSPE-PEG insertion, both unloaded and loaded LNCs showed a dramatic decrease of zeta potential.

\section{Table 1}

Physico-chemical characteristics (size and charge) of conventional and stealth LNCs unloaded and loaded with FcOHTAM.

\begin{tabular}{lll}
\hline Formulation & Hydrodynamic diameter $(\mathrm{nm})$ & Zeta potential $(\mathrm{mV})$ \\
\hline LNCs & $51.2 \pm 0.7$ & $-6.6 \pm 0.5$ \\
Stealth LNCs & $54.9 \pm 0.9$ & $-24.8 \pm 1.3$ \\
FcOHTAM-LNCs & $51.3 \pm 0.4$ & $+22.7 \pm 0.4$ \\
Stealth FcOHTAM-LNCs & $53.9 \pm 0.6$ & $-13.0 \pm 1.9$ \\
\hline
\end{tabular}

\subsection{In vitro antiproliferative activity}


The antiproliferative activity of FcOHTAM loaded LNCs was assessed comparatively to free FcOHTAM using the MTS assay after exposure of MDA-MB-231 cells to different drug concentrations ranging from $0.01 \mu \mathrm{M}$ to $100 \mu \mathrm{M}$ for $72 \mathrm{~h}$. The cell survival profiles of the various treatments were illustrated in Fig. 2.

As shown in Fig. 2, the FcOHTAM concentrations which inhibit the cell growth at 50\% $\left(\mathrm{IC}_{50}\right)$ remain unchanged after entrapment into LNCs whatever the types of LNCs (conventional or stealth), reaching an interesting low value around $2 \mu \mathrm{M}$. At this dilution, vehicles did not show any toxicity.

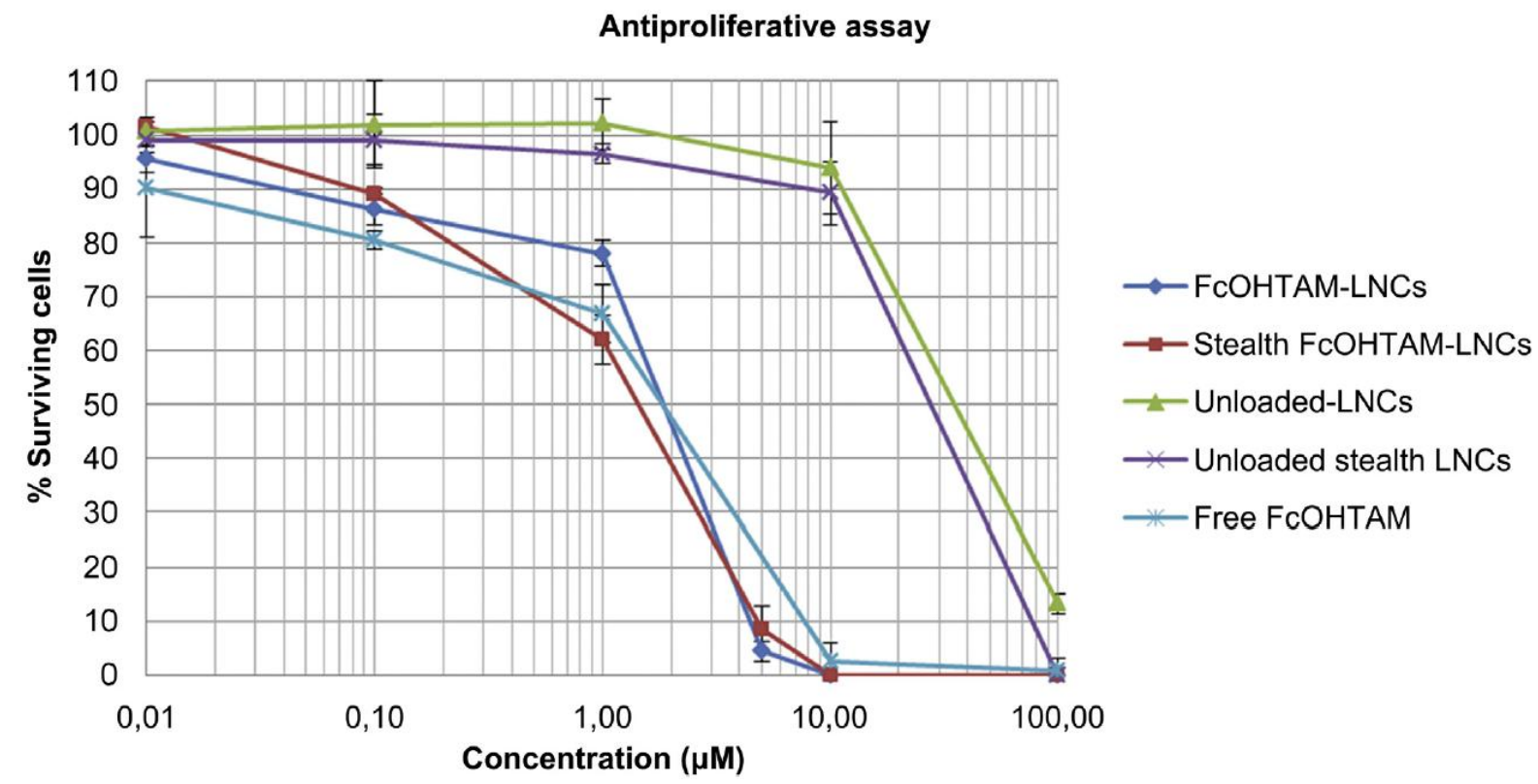

Fig. 2. MDA-MB-231 cell survival curve after $72 \mathrm{~h}$ exposure to various treatments (Free FcOHTAM, FcOHTAM-LNCs, stealth FcOHTAM-LNCs, Unloaded LNCs and Unloaded stealth LNCs) at increasing drug concentration ranging from $0.01 \mu \mathrm{M}-100 \mu \mathrm{M}$. The results are expressed as the mean $\pm \mathrm{SD}$.

\subsection{Cell cycle distribution}

We have previously described that growth inhibitory effect of FcOHTAM is characterized by modification of cell cycle distribution of MDA-MB-231 [15]. In order to evaluate the impact of the drug encapsulation into LNCs on this effect, cell cycle distribution analyses were conducted at $\mathrm{IC}_{50}$ value $(2 \mu \mathrm{M})$ and results were gathered in Fig. 3. Similar cell cycle profiles and cell cycle kinetics were observed for FcOTHAM free or formulated in LNCs or 
stealth-LNCs. Whatever the formulation, FcOHTAM led to a slight increased of MDA-MB231 cells in S-phase fraction after $24 \mathrm{~h}$ of treatment. After $48 \mathrm{~h}$, the cells were stacked mainly in $S$ phase. Then, after $72 \mathrm{~h}$, cells entered in G2/M phase then went back to G0/G1 phase. A sub-G0 population was also detectable indicating that a fraction of the treated cells were dead. 
A

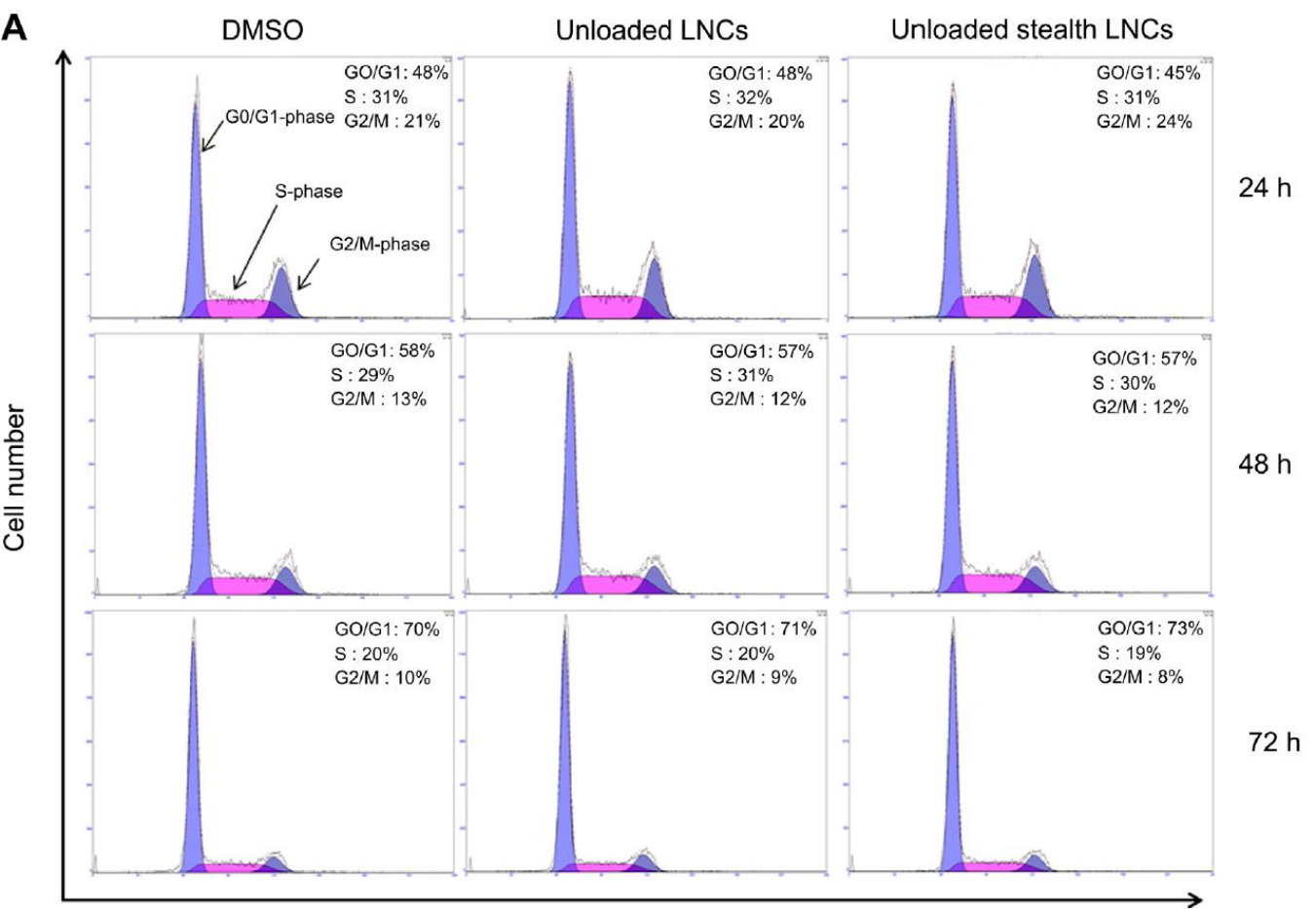

DNA content

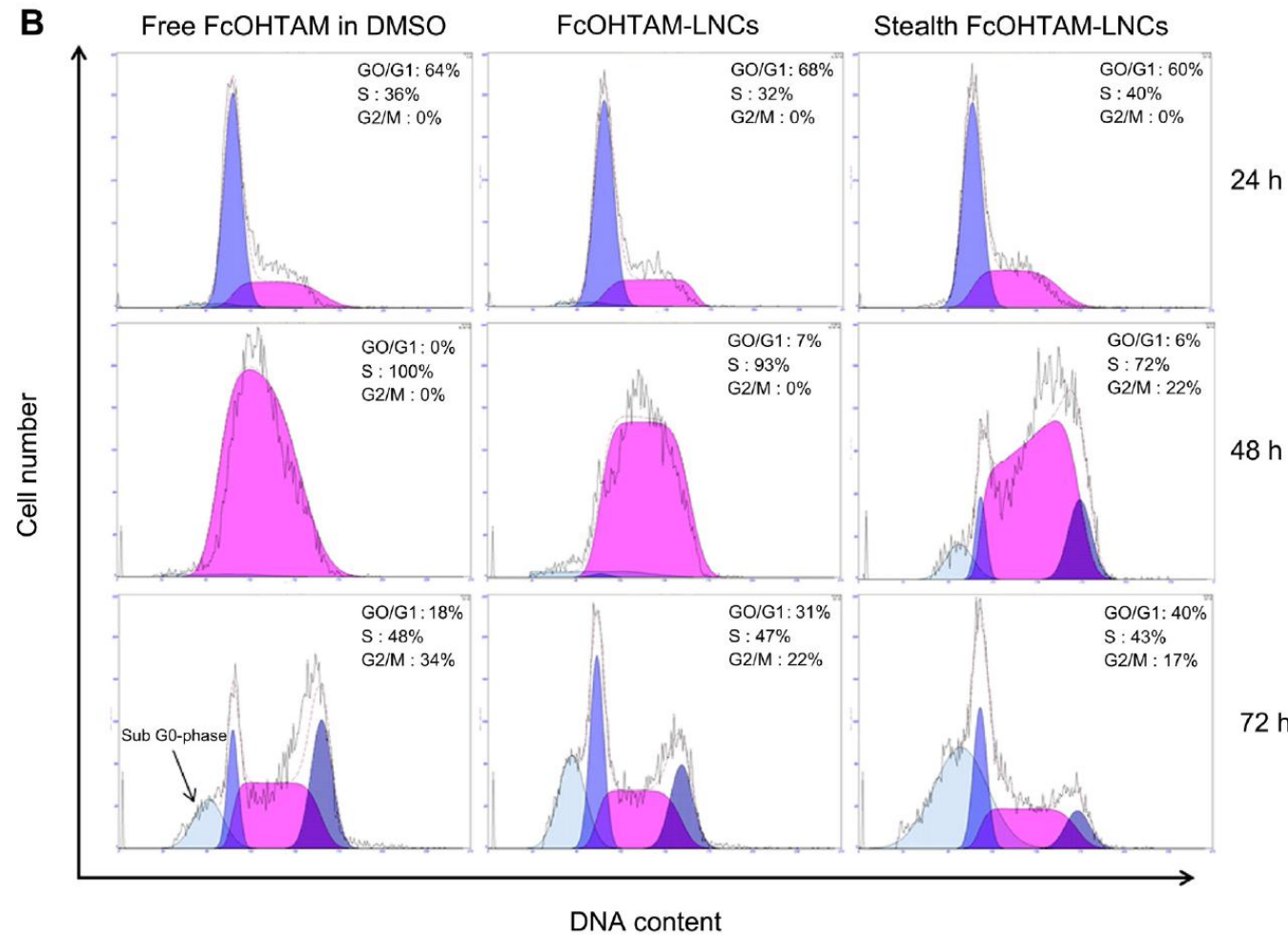

Fig. 3. Typical flow cytometric analysis profile. Breast cancer cells were treated with A) DMSO, LNCs, stealthLNCs, B) Free FcOHTAM in DMSO, FcOHTAM-LNCs or stealth FcOHTAM-LNCs for 24, $48 \mathrm{~h}$ or $72 \mathrm{~h}$, then analyzed by flow cytometry. An example of G0/G1, S and G2/M phase was annotated in A (DMSO at $24 \mathrm{~h}$ ) and an example of sub-G0 peak was visualized in B (free OH-TAM at $72 \mathrm{~h}$ ). The results are representative of two independent experiments. 


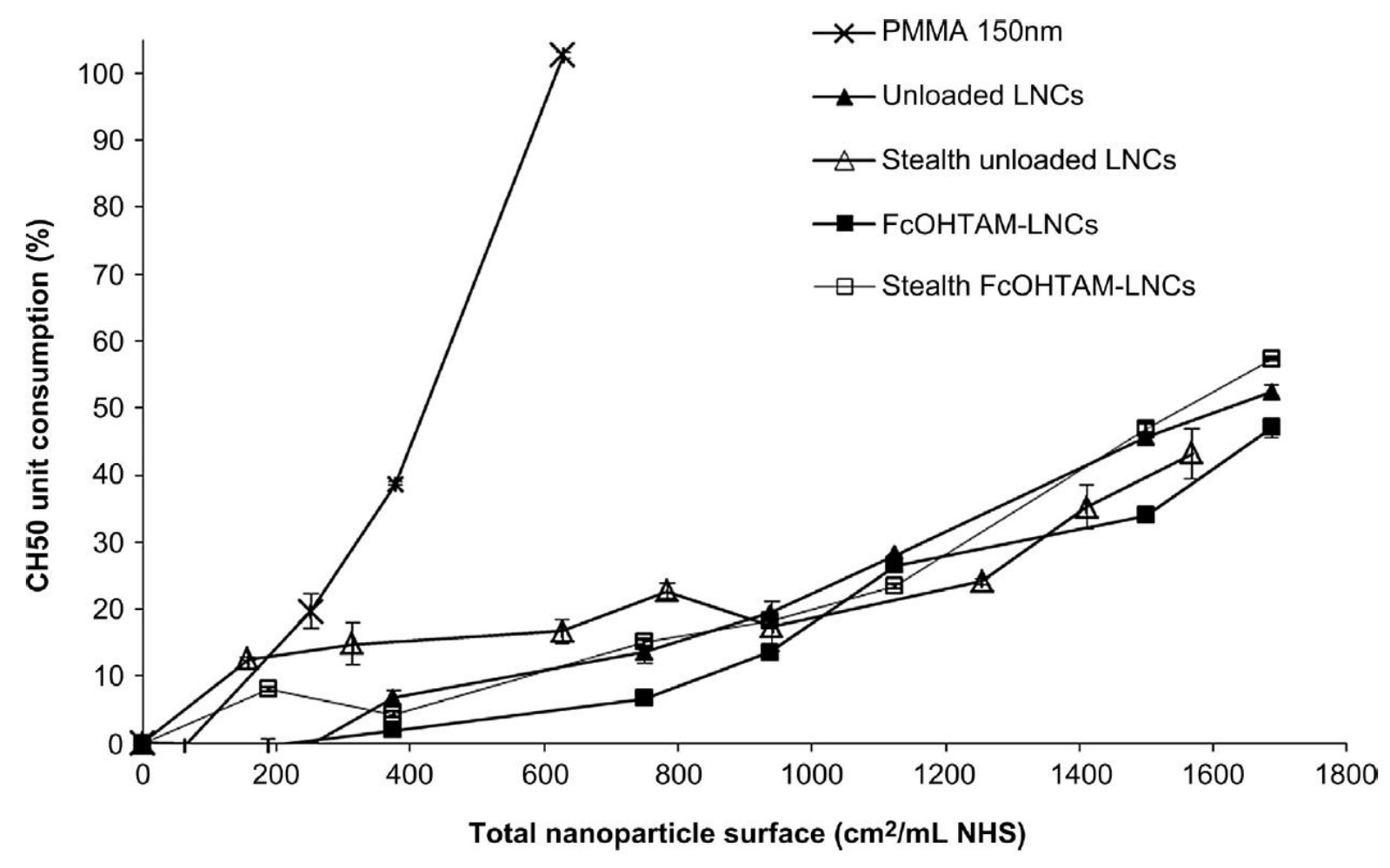

Fig. 4. Complement activation of unloaded LNCs, stealth unloaded LNCs FcOHTAM-LNCs and stealthFcOHTAM-LNCs expressed by $\%$ consumption of $\mathrm{CH} 50$ unit at $37{ }^{\circ} \mathrm{C}$ in function of the nanoparticle surface area. The results are represented as mean \pm SEM.

\subsection{In vitro complement activation}

Upon intraperitoneal injections, the drug-loaded LNCs are expected to be absorbed into the systemic circulation where they can experience a clearance phenomenon due to the immune system. Accordingly, the complement activation was evaluated in vitro by the CH50 method, which measures the complement system activation due to the LNCs [25]. This method consists in determining the residual haemolytic capacity of a fixed amount of normal human serum towards $50 \%$ of antibody-sensitized sheep erythrocytes in the presence of an increasing nanoparticle surface area. As presented in Fig. 4, all types of tested LNCs, namely unloaded LNCs, stealth unloaded LNCs, FcOHTAM-LNCs and stealth FcOHTAM-LNCs, demonstrated weak complement activation compared to the positive control, polymethyl methacrylate (PMMA) nanoparticles, which were considered as strong complement activators [23]. 


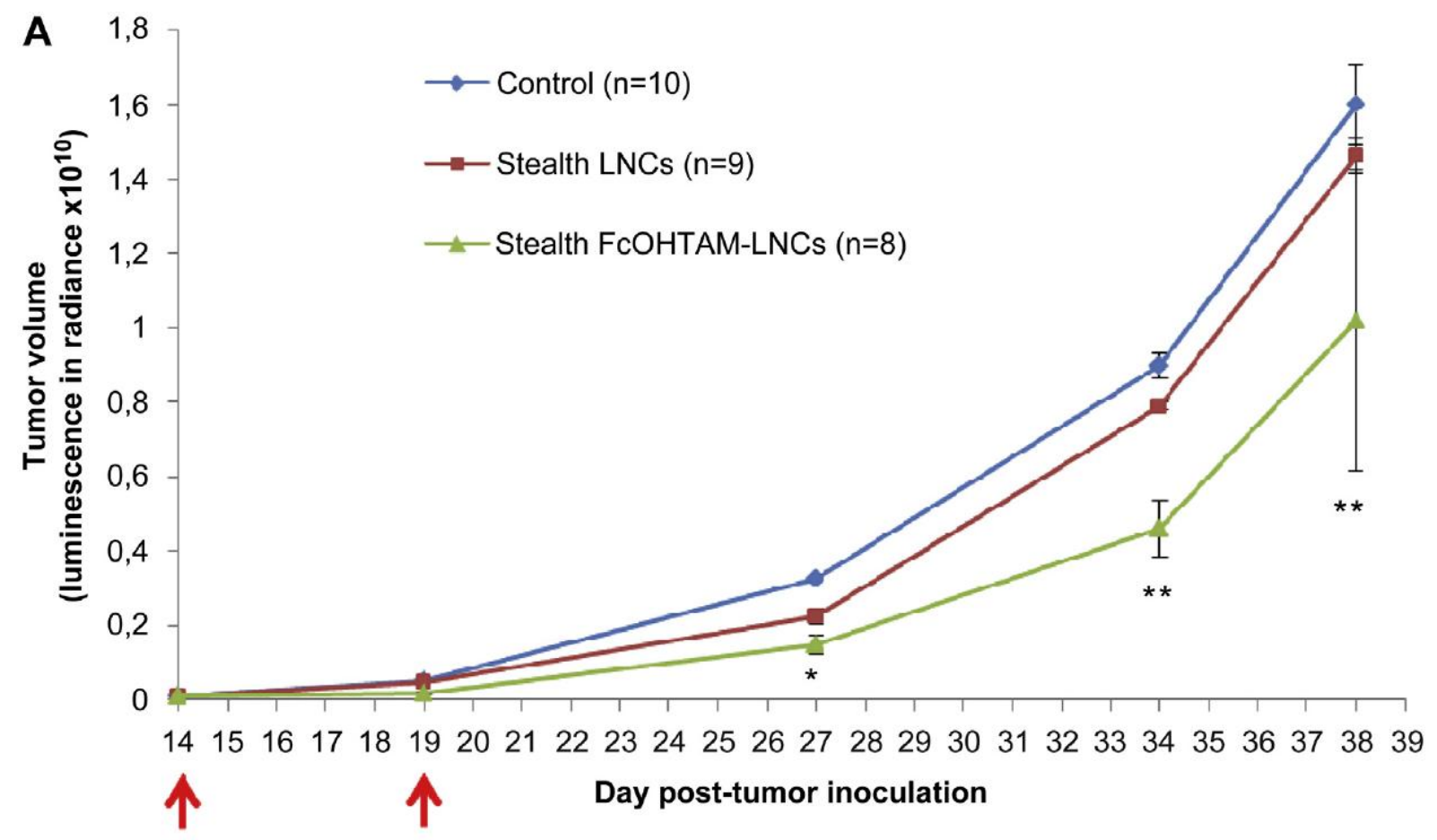

B

\section{Day 14}

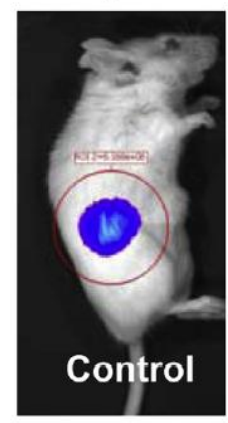

Day 37

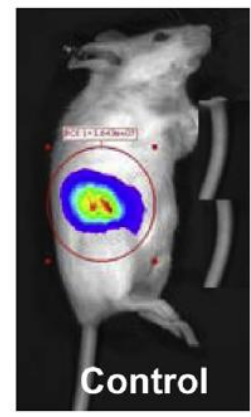

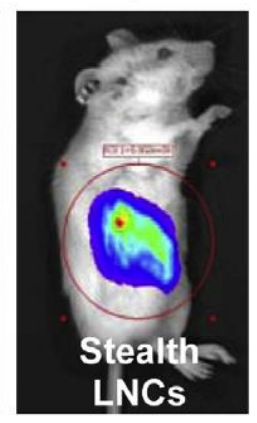

Luminescence

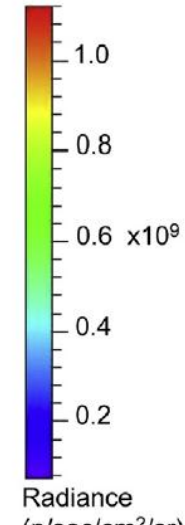

(p/sec/cm²/sr)

Fig. 5. A/ Tumor volume evolution of xenografted MDA-MB-231. SCID mice were injected with MDA-MB231 breast cancer cells expressing luciferase gene (D0). At day 14 and day 19, mice were injected with indicated treatments. To monitoring tumoral volume, mice were subjected to in vivo imaging at day 0, 14, 1927,34 and 38. Luminescence was measured in radiance (pixels $/$ second $/ \mathrm{cm}^{2} / \mathrm{square}$ ). The number of animals used for each group is indicated on the figure. Mann-Withney test was performed between control group and treated groups. The red arrows correspond to the treatment days. The values are expressed as mean $\pm \mathrm{SEM} * \mathrm{P}<0.05, * * \mathrm{P}<$ 0.01, compared with the untreated control. B/ Photographic demonstration of comparative tumor size after treatment. (For interpretation of the references to color in this figure legend, the reader is referred to the web version of this article.) 


\subsection{In vivo antitumor activity of FCOHTAM-LNCs on mice bearing TNBC xenografted}

tumors

The antitumor activity of FcOHTAM was assessed in vivo on a TNBC model subcutaneously xenografted into SCID mice. In order to monitor the tumor growth, MDAMB-231 cells expressing luciferase gene were injected. Intraperitoneal (i.p) route was chosen for drug dosing considering that, for repeated injections, i.p. is more convenient and less invasive than intravenous injection while similar plasma distribution is obtained with both routes. The tumor evolution for each group was plotted in Fig. 5.

Tumor volumes increased dramatically for both untreated control group and unloaded LNC treated group with similar tumor evolutions. Interestingly, FcOHTAM-LNC treatment markedly delayed the tumor growth compared to the two previously mentioned groups. As a result, the hampered tumor growth rate led to an impressive low tumor volume at day 38 with $36 \%$ tumor volume reduction compared to that of control groups $(\mathrm{P}<0.01)$ (Fig. 5A) as evidenced by the pictures of tumor luminescence (Fig. 5B).

\section{Discussion}

Triple negative breast cancer, defined by the absence of estrogen receptor alpha, progesterone receptor and HER2 expression, is characterized by a high rate of relapse and widespread metastases reflected in a poorer prognosis and a higher mortality number than other BC subtypes. As the current therapies with conventional cytotoxics fail to hamper its aggressive evolution, TNBC treatment remains a great clinical challenge.

Since the discovery of cisplatin, one of the most potent anticancer drugs, albeit ineffective to cure breast cancer, the interest in metal-based drugs has been growing in an attempt to overcome the therapeutic limitations encountered with available organic compounds [26]. In this context, a ferrocenyl-based tamoxifen has been synthesized to confer additional 
properties to the tamoxifen drug alone including accessible redox state. Whereas tamoxifen shows an antiproliferative effect on hormone-dependent cell lines only, the ferrocene moiety extended its anticancer activity to $\mathrm{ER} \alpha(-)$ cell lines and TNBC cell lines. Considering this hopeful result, this paper aimed to evaluate the antitumor activity of this metal-based drug in a TNBC xenograft model. The poor water solubility of this lipophilic drug required the use of a dosage form for its in vivo injection. Lipid nanocapsules were suitable candidates as they already achieved great outcomes in terms of loading capacity of FcdiOH, another ferrocenyl based drug, and successful transport toward the site of interest [20].

Regarding FcOHTAM, its encapsulation into LNCs turned out to be readily feasible at suitable concentration $(8 \mathrm{mg} / \mathrm{mL})$. FcOHTAM-LNCs displayed a high positive zeta potential probably due to the positively charged amino moiety of FcOHTAM, suggesting that the compound was entrapped within the shell of the LNCs and exposed at the interface water/oil. This drug anchorage at the surface might prevent its escape into an undesired site on its way toward the tumor. However, positively charged nanoparticles have shown to exhibit high systemic toxicity $[27,28]$. To rend the nanocapsules safe for animal injection, a PEGylation was performed providing a negatively charged hairy surface. This DSPE-mPEG insertion effect on zeta potential is consistent with previous reports and could be explained through the following two considerations. Firstly, the slipping plane is moved further away from the nanocapsule surface due to the 45 ethylene oxide units composing the phospholipid PEG [29]. In addition, the reduction of the charge can also be due to the negatively charged phosphate groups of DSPE-mPEG [30].

Beside a surface charge modification, the grafting of PEGylated phospholipids is also used to provide nanoparticles with stealth properties [29,31]. Upon intraperitoneal injection and after absorption into the systemic circulation, the LNCs are subjected to elimination phenomena due to the immune system. To avoid a rapid clearance and increase the drug 
accumulation into the tumor, galenists made use of PEGylation techniques, referred to as the coating of nanoparticles surface with polyethylene glycol resulting in the formation of a hydrodynamic layer. The DSPE-mPEG2000 post-insertion method already proved to be efficient, permitting a significant

extension of LNCs circulation time in plasma [22,32]. Here, FcOHTAM-LNCs post-inserted with DSPE-mPEG showed low in vitro complement activation predicting stealth properties upon in vivo injection.

In order to make sure that the FcOHTAM activity was not hampered by the lipid nanocapsules, in vitro antiproliferative assay and cell cycle distribution were run. Equivalent activity profiles were obtained for free FcOHTAM and stealth FcOHTAM-LNCs on a TNBC cell line with low $\mathrm{IC}_{50}$ values of $2 \mu \mathrm{M}$ and, as previously described, an $\mathrm{S}$ phase cell cycle arrest after a two day treatment at this $\mathrm{IC}_{50}$ values, [15]. This indicated that $\mathrm{LNC}$ did not significantly modify the FcOHTAM biological effects on cells. It is worth noting that the $\mathrm{IC}_{50}$ of free OH-TAM for the same cells (MDA-MB-231) is above $30 \mu \mathrm{M}$ [33]. By comparison to the literature, FcOHTAM-LNCs showed 10-20-fold lower $\mathrm{IC}_{50}$ value compared to other drugs under investigation on this cell line such as curcumin $(\sim 20 \mu \mathrm{m})[34]$ and noscapine $(\sim 36 \mu \mathrm{m})$ [35] but remains higher than those of the first-line drugs used for the management of hormone independent breast cancer including doxorubicin $(0.04 \mu \mathrm{M})$ or paclitaxel $(5 \mathrm{nM})$ [36]. However, the cell cycle analysis of FcOHTAM-LNCs and previous studies proving the absence of DNA alteration with FcOHTAM treatment [37] seemed to reveal an original cell death pathway mediated by senescence. Although low doses of doxorubicin were shown to induce senescence $[38,39]$, its major effect is related to the apoptosis cell death. Thus, FcOHTAM effects occurred by an alternative cell death pathway different from the DNA intercaling activity of doxorubicin [40,41] and from the microtubule-stabilizing effect 
ascribed to paclitaxel [42]. This might bring a new strategy to overcome the resistance developed in clinics by the cells treated with either drug.

To further assess the antitumor effects of FcOHTAM-LNCs, in vivo study was performed on mice bearing luciferase-transfected MDA-MB-231 cancer cells, a TNBC model resistant to OH-TAM. The use of this kind of cancer model allows a rapid and non-invasive monitoring of the tumor via the bioluminescent imaging technique.

Whereas control groups including untreated animals and unloaded LNC treatment showed an impressive fast tumor growth, treatment with stealth FcOHTAM-LNCs led to a marked delay of the tumor growth. Two main areas can be distinguished according to the curve slopes, one between D19 and D34 and the second one from D34. In the first area, the FcOHTAM-LNCs curve slope does not parallel the control slope, evidencing the cytostatic effect of the treatment on cell proliferation. Consequently, at D34 the tumor volume of stealth FcOHTAM-LNCs treated group was half that of the control group. On the contrary, the equivalent slopes between the treated and control groups in the second part of the graph demonstrate the cell metabolism recovery for the FcOHTAM-LNC-treated tumors. This recovery led to a reduced gap estimated at $36 \%$ between the tumor volumes of treated and control groups. This result suggests that, in order to curtail the tumor regrowth, additional injections may be necessary.

This result represents the first evidence of an in vivo effect of a ferrocenyl derivative on xenografted breast cancer tumors and to the best of our knowledge, it is also the first novel chemical molecule proving activity on MDA-MB-231 cell lines. As previously shown, the anticancer biological mechanism of FcOHTAM involves ROS production, oxidation of iron $(+2)$ in iron (+3), and generation of quinone methide [43] which is ultimately associated with S-phase cell cycle arrest and senescence. The current therapies used in clinics to treat TNBC include anthracyclines and taxane. Although certain TNBC cases positively respond to these 
molecules, the overall survival remained poor and is referred to as "TNBC paradox" [3]. Consequently, with its original mechanism of action, FcOHTAM might represent a promising treatment option for TNB cancers.

The next step for the evaluation of this drug would be to assess its efficiency in a metastatic breast cancer model. Metastatic breast cancer is the most advanced stage and the main cause of mortality for breast cancer patients [44]. While current researches are focusing on the elucidation of metastasis process [45-47], to date, there is no curable solution and treatments merely aim to relieve symptoms and extending a woman's life expectancy. Generally, systemic chemotherapy is used in metastatic cancer treatment ensuring the drug distribution through the whole body in order to reach most of the tumor sites. Stealth LNCs are specially designed to escape the immune system, thus prolonging the circulation time in body fluids and would be really adapted to the evaluation of FcOHTAM in a metastatic breast cancer model.

Finally, the dual antagonist/agonist action displayed by TAM may increase the probability of developing endometrial cancer among other side effects. Thanks to LNC, it would be possible to attach targeting agents onto their surface in order to carry the drug selectively to the designated tumor site without harming healthy cells.

\section{Conclusion}

This work has evidenced the potent anticancer activity of the ferrocenyl tamoxifen on a xenografted breast cancer. Even if additional studies are needed to further evidence this observed anticancer activity, FcOHTAM-LNCs could represent an alternative and efficient strategy to fight this so far incurable cancer.

\section{Acknowledgment}


The authors would like to thank Nolwenn Lautram (Inserm U1066) for her technical assistance in complement activation assay. This work was supported by the ANRBlanc program Mecaferrol.

\section{References}

[1] Jemal A, Bray F, Center MM, Ferlay J, Ward E, Forman D. Global cancer statistics. CA Cancer J Clin 2011;61:69-90.

[2] Lehmann BD, Bauer JA, Chen X, Sanders ME, Chakravarthy AB, Shyr Y, et al. Identification of human triple-negative breast cancer subtypes and preclinical models for selection of targeted therapies. J Clin Invest 2011;121:2750-67.

[3] De Laurentiis M, Cianniello D, Caputo R, Stanzione B, Arpino G, Cinieri S, et al. Treatment of triple negative breast cancer (TNBC): current options and future perspectives. Cancer Treat Rev 2010;36(Suppl. 3):S80-6.

[4] Clemons M, Danson S, Howell A. Tamoxifen ("Nolvadex"): a review: antitumour treatment. Cancer Treat Rev 2002;28:165-80.

[5] Oakman C, Viale G, Di Leo A. Management of triple negative breast cancer. Breast 2010;19:312-21.

[6] Lainé A-L, Passirani C. Novel metal-based anticancer drugs: a new challenge in drug delivery. Curr Opin Pharmacol 2012;12:420-6.

[7] Nguyen A, Vessieres A, Hillard EA, Top S, Pigeon P, Jaouen G. Ferrocifens and ferrocifenols as new potential weapons against breast cancer. Chimia 2007;61:716-24.

[8] Jordan VC. Tamoxifen (ICI46,474) as a targeted therapy to treat and prevent breast cancer. $\mathrm{Br}$ J Pharmacol 2006;147(Suppl. 1):S269-76. 
[9] Ameller T, Legrand P, Marsaud V, Renoir J- M. Drug delivery systems for oestrogenic hormones and antagonists: the need for selective targeting in estradiol-dependent cancers. $\mathbf{J}$ Steroid Biochem Mol Biol 2004;92:1-18.

[10] Riggins RB, Schrecengost RS, Guerrero MS, Bouton AH. Pathways to tamoxifen resistance. Cancer Lett 2007;256:1-24.

[11] Ring A, Dowsett M. Mechanisms of tamoxifen resistance. Endocr Relat Cancer 2004;11:64358.

[12] Tergas AI, Buell-Gutbrod R, Gwin K, Kocherginsky M, Temkin SM, Fefferman A, et al. Clinico-pathologic comparison of type II endometrial cancers based on tamoxifen exposure. Gynecol Oncol 2012;127:316-20.

[13] Metindir J, Aslan S, Bilir G. Ovarian cyst formation in patients using tamoxifen for breast cancer. Jpn J Clin Oncol 2005;35:607-11.

[14] Hanstein B, Djahansouzi S, Dall P, Beckmann MW, Bender HG. Insights into the molecular biology of the estrogen receptor define novel therapeutic targets for breast cancer. Eur $\mathbf{J}$ Endocrinol 2004;150:243-55.

[15] Vessières A, Corbet C, Heldt JM, Lories N, Jouy N, Laïos I, et al. A ferrocenyl derivative of hydroxytamoxifen elicits an estrogen receptor-independent mechanism of action in breast cancer cell lines. J Inorg Biochem 2010;104:503-11.

[16] Mandlekar S, Kong AN. Mechanisms of tamoxifen-induced apoptosis. Apoptosis 2001;6:46977.

[17] Huynh NT, Passirani C, Saulnier P, Benoit JP. Lipid nanocapsules: a new platform for nanomedicine. Int J Pharm 2009;379:201-9.

[18] Laine A-L, Huynh NT, Clavreul A, Balzeau J, Béjaud J, Vessieres A, et al. Brain tumour targeting strategies via coated ferrociphenol lipid nanocapsules. Eur J Pharm Biopharm 2012;81:690-3. 
[19] Allard E, Huynh NT, Vessières A, Pigeon P, Jaouen G, Benoit J-P, et al. Dose effect activity of ferrocifen-loaded lipid nanocapsules on a 9L-glioma model. Int J Pharm 2009;379:317-23.

[20] Huynh NT, Morille M, Bejaud J, Legras P, Vessieres A, Jaouen G, et al. Treatment of 9L gliosarcoma in rats by ferrociphenol-loaded lipid nanocapsules based on a passive targeting strategy via the EPR effect. Pharm Res 2011;28:3189-98.

[21] Top S, Vessières A, Leclercq G, Quivy J, Tang J, Vaissermann J, et al. Synthesis, biochemical properties and molecular modelling studies of organometallic specific estrogen receptor modulators (SERMs), the ferrocifens and hydroxyferrocifens: evidence for an antiproliferative effect of hydroxyferrocifens on both hormone-dependent and hormone-independent breast cancer cell lines. Chemistry 2003;9:5223-36.

[22] Morille M, Montier T, Legras P, Carmoy N, Brodin P, Pitard B, et al. Long-circulating DNA lipid nanocapsules as new vector for passive tumor targeting. Biomaterials 2010;31:321-9.

[23] Vonarbourg A, Passirani C, Saulnier P, Simard P, Leroux JC, Benoit JP. Evaluation of pegylated lipid nanocapsules versus complement system activation and macrophage uptake. $\mathbf{J}$ Biomed Mater Res A 2006;78:620-8.

[24] Passirani C, Barratt G, Devissaguet JP, Labarre D. Interactions of nanoparticles bearing heparin or dextran covalently bound to poly(methyl methacrylate) with the complement system. Life Sci 1998;62:775-85.

[25] Vonarbourg A, Passirani C, Saulnier P, Benoit J-P. Parameters influencing the stealthiness of colloidal drug delivery systems. Biomaterials 2006;27:4356-73.

[26] Gasser G, Ott I, Metzler-Nolte N. Organometallic anticancer compounds. J Med Chem $2011 ; 54: 3-25$.

[27] Kedmi R, Ben-Arie N, Peer D. The systemic toxicity of positively charged lipid nanoparticles and the role of Toll-like receptor 4 in immune activation. Biomaterials 2010;31:6867-75. 
[28] Naahidi S, Jafari M, Edalat F, Raymond K, Khademhosseini A, Chen P. Biocompatibility of engineered nanoparticles for drug delivery. J Control Release 2013;166:182-94.

[29] Kim J-Y, Kim J-K, Park J-S, Byun Y, Kim C-K. The use of PEGylated liposomes to prolong circulation lifetimes of tissue plasminogen activator. Biomaterials 2009;30:5751-6.

[30] Hinrichs WLJ, Manceñido FA, Sanders NN, Braeckmans K, De Smedt SC, Demeester J, et al. The choice of a suitable oligosaccharide to prevent aggregation of PEGylated nanoparticles during freeze thawing and freeze drying. Int J Pharm 2006;311:237-44.

[31] Jokerst JV, Lobovkina T, Zare RN, Gambhir SS. Nanoparticle PEGylation for imaging and therapy. Nanomedicine (Lond) 2011;6:715-28.

[32] Hoarau D, Delmas P, David S, Roux E, Leroux J-C. Novel long-circulating lipid nanocapsules. Pharm Res 2004;21:1783-9.

[33] Zhang F, Fan PW, Liu X, Shen L, van Breeman RB, Bolton JL. Synthesis and reactivity of a potential carcinogenic metabolite of tamoxifen: 3,4-dihydroxytamoxifen-o-quinone. Chem Res Toxicol 2000;13:53-62.

[34] Sun S-H, Huang H-C, Huang C, Lin J-K. Cycle arrest and apoptosis in MDA-MB-231/Her2 cells induced by curcumin. Eur J Pharmacol 2012;690:22-30.

[35] Chougule MB, Patel AR, Jackson T, Singh M. Antitumor activity of noscapine in combination with doxorubicin in triple negative breast cancer. PLoS One 2011;6:e17733.

[36] Kirson ED, Schneiderman RS, Dbalý V, Tovarys F, Vymazal J, Itzhaki A, et al. Chemotherapeutic treatment efficacy and sensitivity are increased by adjuvant alternating electric fields (TTFields). BMC Med Phys 2009;9:1.

[37] Osella D, Mahboobi H, Colangelo D, Cavigiolio G, Vessières A, Jaouen G. FACS analysis of oxidative stress induced on tumour cells by SERMs. Inorganica Chim Acta 2005;358:1993-8.

[38] Roninson IB. Tumor cell senescence in cancer treatment. Cancer Res 2003;63:2705-15. 
[39] Eom Y-W, Kim MA, Park SS, Goo MJ, Kwon HJ, Sohn S, et al. Two distinct modes of cell death induced by doxorubicin: apoptosis and cell death through mitotic catastrophe accompanied by senescence-like phenotype. Oncogene 2005;24:4765-77.

[40] Tacar O, Sriamornsak P, Dass CR. Doxorubicin: an update on anticancer molecular action, toxicity and novel drug delivery systems. J Pharm Pharmacol 2013;65:157-70.

[41] Bar-On O, Shapira M, Hershko DD. Differential effects of doxorubicin treatment on cell cycle arrest and Skp2 expression in breast cancer cells. Anticancer Drugs 2007;18:1113-21.

[42] Flores ML, Castilla C, Ávila R, Ruiz-Borrego M, Sáez C, Japón MA. Paclitaxel sensitivity of breast cancer cells requires efficient mitotic arrest and disruption of Bcl-xL/Bak interaction. Breast Cancer Res Treat 2011;133:917-28.

[43] Hillard E, Vessières A, Thouin L, Jaouen G, Amatore C. Ferrocene-mediated proton-coupled electron transfer in a series of ferrocifen-type breast-cancer drug candidates. Angew Chem Int Ed Engl 2006;45:285-90.

[44] Weigelt B, Peterse JL, van't Veer LJ. Breast cancer metastasis: markers and models. Nat Rev Cancer 2005;5:591-602.

[45] Liang Z, Yoon Y, Votaw J, Goodman MM, Williams L, Shim H. Silencing of CXCR4 blocks breast cancer metastasis. Cancer Res 2005;65:967-71.

[46] Fantozzi A, Christofori G. Mouse models of breast cancer metastasis. Breast Cancer Res $2006 ; 8: 212$.

[47] Dewan MZ, Terunuma H, Ahmed S, Ohba K, Takada M, Tanaka Y, et al. Natural killer cells in breast cancer cell growth and metastasis in SCID mice. Biomed Pharmacother 2005;59(Suppl. 2):S375-9. 